\title{
Have Families Been Rethought? Ethic of Care, Family and 'Whole Family' Approaches
}

\author{
Lesley Murray*and Marian Barnes** \\ * Social Science Policy and Research Centre, School of Applied Social Science, University of Brighton \\ E-mail: L.Murray@brighton.ac.uk \\ ** Social Science Policy and Research Centre, School of Applied Social Science, University of Brighton \\ E-mail: Marian.Barnes@brighton.ac.uk
}

'Whole family' approaches to intervention and prevention have raised the profile of 'family' within social policy, where the family is constructed as a site of child care and protection, neglect and disadvantage. However, 'family' is a taken-for-granted and narrowly defined concept within policy documentation, and often used interchangeably with 'parents.' This paper uses Sevenhuijsen's (2003) 'Trace' approach to explore the use of the concept of 'family' across a number of interrelated social policy streams. The efficacy of familial approaches is considered through a feminist ethic of care approach that questions both gendered and generational assumptions about families in practice.

\section{Introduction}

The term 'family' has become rooted in UK social policy, particularly in policy focussing on managing risk to children. This is most discernible in the Cabinet Office's Social Exclusion Task Force Families at Risk Review (SETF, 2007), which used the term Think Family to focus attention on the need to integrate both intervention and prevention strategies aimed at the 'family' as a discrete unit. This article reviews the range of policy streams that foreground 'family' as an ideology and a site for action, reflecting this embedding (Gubrium and Holstein, 1990) of family in UK policy institutions. The discussion is framed by previous explorations of family, in particular Williams' (2004) Rethinking Families and the Morris et al. (2008) literature review of whole family approaches. It is based on analysis of policy documents from an ethic of care approach (Sevenhuijsen, 2003) and discursive analysis of family policy (Gubrium and Holstein, 1990).

\section{Defining family}

The family as a specific blend of social relations has been constructed and re-constructed in many forms throughout history (Gubrium and Holstein, 1990; Beck and BeckGernsheim, 1995; Clarke, 1996; Silva and Smart, 1999). The myriad conceptualisations of family reflect socio-cultural, economic, political, temporal and spatial contexts. Family can be kin and non-kin, and is often about care and trust in the context of enduring relationships. It has been a key site for debates concerning private and public responsibilities and gender relations. Concepts of family embody both ideological and practical dimensions. 
Discourses of family reflect this two-fold nature, in that they can be 'substantive' and 'active' (Gubrium and Holstein, 1990). Substantive discourses are based on terminology, ideas, models and theories, whilst active discourses refer to the practices of family in everyday life. These sets of actions and meanings are themselves dependent on the available discourses of family. Gubrium and Holstein argue that discourses become 'organisationally embedded' - a particular discourse is ascribed to a particular organisation, be it a discrete unit such as an institution or more broadly a particular professional group (e.g. social workers). In this way, practitioners are complicit in determining discourses of family through constant interpretation of the 'recognisable features of everyday life' in order to 'assemble the coherent social realities they inhabit' (Gubrium and Holstein, 1990: 117).

Williams (2004) book Rethinking Families, which summarises insights from the research programme Care, Values and the Future of Welfare (CAVA) discusses how the new normative family is taking shape and the extent to which this notion of family compares with lived experience. Williams (2004: 38) identifies the need to look at what 'family' is as a functional relationship rather than as a definition based on co-residence or traditional norms, arguing that 'there are gaps between the ought and the is'. The outcomes of the CAVA programme included the need to develop a practical 'ethic of care' where 'autonomy and independence' relate to 'self-determination' rather than 'individual selfsufficiency', with calls for a greater emphasis on solidarity, reciprocity, commitment and love (Williams, 2003: 6).

Morris et al. (2008) identified a lack of research into the everyday lived experiences of families with multiple difficulties, particularly more marginalised families. They defined 'family' as: 'self-determined' and 'unique' to each family member; 'inclusive and not simply grounded in immediacy' or 'proximity'; 'un-boundaried' and inconsistently used. As well as highlighting the lack of a coherent approach to the definition of the term 'family', Morris et al. found that much of the literature around the family is based on parenting, and in particular parenting strategies that centre on mothers.

\section{Parenting and the family}

The structure of the family in the UK is changing, with, in particular, an increase in single parenthood and a corresponding feminisation of childhood (Duncan and Edwards, 1999; Silva and Smart, 1999). Normative constructions of the 'good' 'nuclear' family are increasingly less relevant to family practice (Clarke, 1996). These constructions are gendered in that they centre on the 'good' mother (Chase and Rogers, 2001) and generational as, in particular, children's agency (James et al., 1998) is often underplayed in defining carers and cared for within families.

Although recognising the role of individualisation in defining relationships (e.g. Beck and Beck-Gernsheim, 1995), the practices of family are predicated on shared and situated relationships of care. As such, changes in family structure are not a 'sign of decline or immorality' but an establishment of 'families as agents of self-reflexivity, actively interacting with the wider environment' (Silva and Smart, 1999: 2). Silva and Smart argue that 'families remain a crucial relational entity playing a fundamental part in the intimate life of and connections between individuals'. Contrary to idealised notions of a 'good' family, they usefully suggest that 'families are what families do' (Silva and Smart, 1999: 5). 
Normative assumptions relating to the family as the most nurturing context for childhood development are premised on the legitimation of modern approaches to child rearing, and the protection of established notions of childhood as a means of investment in and safeguards for the future (Hendrick, 2003). As uncertainty increases in late modernity, the child is seen as a form of stability and a means of constructing identity in an increasingly individualised world (Beck and Beck-Gernsheim, 1995). Thus the family is used as a means of social control as it is given an increasing role in terms of child welfare, through, for example, the 1989 Children Act, which linked parental authority to responsible behaviour (Hendrick, 2003).

Wider debates based on broadening the notion of family to reflect everyday practices of family challenge normative assumptions, and indeed the efficacy of theorising caring relationships according to familial ties (e.g. Finch, 1989; Smart and Neale, 1999). Based on these debates, a broad definition of family that encompasses the everyday living of 'family' includes recognition of the range of people that are crucial to the social functioning of social units, which is not confined to kin relationships. It recognises the role of children, young people and older people, not only as care receivers but as integral to wider relationships of care. Such relationships are not necessarily child-centred and therefore 'family' embraces those who do not have a child-caring role. It also acknowledges that the family is fluid and ever changing in social space. Families are increasingly 'transnational'. Family members who have a sustained interest in or sense of responsibility in relation to, for example, older parents, but do not live close by, are identified as 'detached carers'. Socially constructed space, not necessarily proximity, is an important and neglected dimension in understanding family.

This paper seeks to contribute to these wider debates through exploring normative assumptions about family and understanding the extent of institutional embedding of these assumptions within policy documents. This analysis used the Trace approach developed by Sevenhuijsen (2003).

\section{Tracing a whole family approach}

Sevenhuijsen (2003) formulated a method for the analysis of policy documents, based on an epistemological approach that draws from feminism and the ethic of care (Tronto, 1993). Sevenhuijsen is critical of normative assumptions of family that are gendered and based on privatised notions of care. We also take a critical approach to normative constructions of family, but recognise that this term can be used to refer to wider care relations that are evident in the everyday practices of family. We propose that care is not only gendered but equally encompasses generational assumptions, in relation both to the role of people of certain ages, and the pattern of care associated with particular stages in the lifecourse. In this way, children, young people and older people are positioned within the realm of care according to normative assumptions and family members without children are rarely positioned at all.

'The main goal of Trace is to - literally - trace the normative framework(s) in policy reports' Sevenhuijsen (2003: 1). It derives from feminist scholarship that has sought to 'de-privatise' and 'de-gender' care, but also to expand our concept of citizenship through including care within this. Trace is used here as a point of departure for a structured analysis of policy documents that place 'family' as a key social unit. The term 'family' 
is traced through these documents using the approach set out in detail by Sevenhuijsen (2003) and situated within both the specific document and wider government policy.

The Think Family stream of policy (Department for Children, Schools and Families (DCSF)) provided the starting point for decisions around inclusion of documents to be analysed, as this embodies the Government's embracing of a 'whole family' approach (SETF, 2006). From here relevant documents provided links to policy streams in social exclusion (Cabinet Office Social Exclusion Task Force (SETF)), social care (Department of Health (DoH)) and anti-social behaviour (Home Office). In seeking to explore how 'family' is constructed through policy streams that were not explicitly linked to 'Think family', we also included three further examples of policy that uses 'family': Building Britain's Future (Department for Work and Pensions (DWP)), the Department for Transport's (DfT) social inclusion policy stream and the Department of Communities and Local Government (DCLG) focus on neighbourhood renewal. In total, 26 documents were analysed across seven policy streams. ${ }^{1}$

\section{Thinking family}

The Think Family approach advocates a fourfold strategy to be incorporated into all support services involved in preventative and intervention strategies to address social exclusion: 'No wrong door', where contact with any service should open avenues to further support as required; 'Look at the whole family', where service should look at working with 'both adults and children [taking] into account family circumstances and responsibilities'; 'Build on family strengths', where practitioners should work in partnership with families, building resilience; and 'Provide support tailored to need', where tailored and family centred packages of support should be offered to all families at risk (Cabinet Office, 2008).

The term 'whole family' suggests an inclusive approach encompassing different relationships. Indeed Think Family is promoted as a holistic and multi-service approach to tackling problems encountered by socially excluded families. The Cabinet Office's Families at Risk Review (SETF, 2007: 29) states that:

The 'whole family' approach does not have to be limited to a strict notion of the family. It may involve the re-framing of responsibilities to the wider community - the family agreeing not to behave in an anti-social manner, for example. It can also involve drawing on friends, kin-carers, networks of support and the wider community as sources of social capital to help a family through adversity.

However, this inclusive perspective is not developed in this and in other documents reviewed.

Another feature of Think Family is the emphasis on the integration of services across government departments. There is some evidence of this with numerous references to Think Family in the DoH's (2008) strategy for carers. However, the discrete family 'unit', defined as parents and children, is by far the most prominent image of family. For example, a Cabinet Office follow-up to the SETF report (2008) advocates the need for a 'whole family' approach so that adults can become more effective parents. This not only ignores children's agency, but also the needs of adults, irrespective of their role as parent. And the notion of 'whole family' is conspicuously absent in many of the documents reviewed, even 
some of those published within the DCSF. For example, the HM Treasury/DCSF's (2007: 39) Aiming High for Disabled Children: Better Support for Families does not mention 'whole family', although it does discuss the 'maze of services' that families with disabled children have to go through to gain support.

The two flagship measures proposed in Think Family and designed to support and intervene in family life embody the normative assumptions evident in policy documents. Family Nurse Partnerships (FNPs) (White et al., 2008) involve dedicated health practitioners working with parents through pregnancy and a child's first two years. Family Intervention Projects (FIPs) (Nixon and Parr, 2008a, 2008b; Parr and Nixon, 2008) originated in the Cabinet Office's Social Exclusion Action Plan (SETF, 2006). FIPs involve intensive intervention strategies in working with 'whole' 'anti-social families'. Thus, whilst FNPs emphasise pedagogic models designed to promote 'positive parenting', FIPs are part of the government's emphasis on the integration of efforts to combat anti-social behaviour.

The DCSF claim that Think Family is about 'building family dimension into everything [they] do' (DCSF, 2009: 4); however, in practice this promotes a limited notion of family that embodies different and competing discourses of family life.

\section{Discourses of family}

We have identified four main discourses within the selected documents: the socially excluded family, the responsible family, the anti-social family and the resourceful/risk managing family.

\section{The social excluded family}

The prevention of 'social exclusion' provides one context for the government approach to families and to child welfare (Artaraz et al., 2007; Morris et al., 2008). Government programmes such as Sure Start, which targeted families in deprived areas, and the Children's Fund, which targeted 5-13 year olds across England, were designed to engage families and children considered at risk of social exclusion. The Social Exclusion Unit report on transport and social exclusion defines social exclusion as 'a short-hand term for what can happen when people or areas suffer from a combination of linked problems such as unemployment, poor skills, low incomes, poor housing, high crime, bad health and family breakdown' (SEU, 2003: 146). Family breakdown is thus identified as one indicator of social exclusion. Socially excluded families are also considered to be highly vulnerable, with 'parents who for whatever reason lack the confidence, motivation or time to get involved...' Within these families there are 'generations of disadvantage' (DCSF, 2007).

Socially excluded families are considered to need services, such as Surestart Children's Centres, where intensive support is offered, particularly around parenting (DCSF, 2007). These needs are considered to relate not only to individuals, but to the 'wider family' (SETF, 2008). One of the key problems identified is that of support not reaching the most needy families (DCSF, 2007), including families with disabled children (DoH, 2008).

Socially excluded families are not only positioned as needy, but also as potentially risky. The Cabinet Office's Think Family report (SETF, 2007) refers to the 2 per cent 
of families with 'multiple problems' that can have adverse effects on children, public services and the wider community. The 'basket of indicators' in terms of multiple problems includes: 'no parent in the family is in work; family lives in poor quality or overcrowded housing; no parent has any qualifications; mother has mental health problems; at least one parent has a longstanding limiting illness, disability or infirmity; family has low income (below 60 per cent of the median); or family cannot afford a number of food and clothing items' (SETF, 2007: 9).

\section{The anti-social family}

The anti-social family is a construction that associates families experiencing social exclusion with particular risky and threatening behaviour. Such behaviour threatens not only members of the family itself, but the wider community, and is a drain on public finances (Home Office, 2006). Families are thus either 'good' or 'bad', legitimising calls for both the exercise of civic duty in collaboration against anti-social behaviour, and/or acceptance of punitive measures against family members. The anti-social family, comprised of both the 'individual and families' is a particular problem for 'decent' and 'law-abiding' families (Home Office, 2006).

The Social Exclusion Action Plan (SETF, 2006) distinguishes those families which do 'hard work' to increase educational attainment, and 'challenging' families, who come under the remit of the Respect Action Plan (Home Office, 2006) and other antisocial behaviour strategies. Within this discourse, the 'whole family' is characterised as anti-social, with siblings identified as potential bad influences for offending behaviour (SETF, 2007). Labelling the 'whole family' as troublesome also warrants whole family interventions such as FIPs (SETF, 2007: 43).

Both the socially excluded family and the anti-social family discourses encompass the notion of the '21st century family' (HM Government, 2009), which is typified by new family compositions that represent a break from the traditional 'nuclear' family. Families that have 'broken down' are considered to have the potential to introduce 'more risk factors' (HM Government, 2003). It is stated that a significant number of children will experience 'family breakdown', 'so the support the parents and the wider family, including grandparents, can provide for the child during family break-up is critical to that child's wellbeing and success' (DCSF, 2007: 24). But 'family breakdown' can have different sources: families of disabled children are considered to be less likely to have one or both parents in work, to be more stressed and therefore more likely to break down (DCSF, 2007: 12). Parents are allocated blame through assumptions of 'good' and 'bad' parenting according to the family structures that result. It is more often than not ('bad') parents who are maligned as the propagators of anti-social behaviour in families (Home Office, 2006) and the children who are considered most at risk from social exclusion (DfT, 2006; SETF, 2007; DCSF, 2009).

\section{The responsible family}

Discourses of family responsibility and resourcefulness offer a very different perspective. Families are on the one hand asked to take responsibility in order to be fully functioning as a resource, whilst at the same time it is assumed that they will need certain resources 
in order to take responsibility. The responsible family discourse incorporates socio-liberal values of autonomy, independence, choice, rights and duties (Sevenhuijsen, 2003). Family members become responsible individuals with a duty to maximise choice and the rights of other individuals in the family. Responsibility is a key dimension of 'active citizenship', but as Newman and Tonkens (in press) elaborate, the notion of responsibility cannot simply be understood as something devolved from the state to its citizens. From an ethic of care perspective, responsibility needs to be distinguished from obligation and understood in specific relational and cultural contexts (Sevenhuijsen, 1998). Families do feel responsibilities towards their members (Williams, 2004), but the way in which this affects what parents or other 'carers' determine is 'the right thing to do' in different contexts does not necessarily coincide with official constructions (Barnes, 2006).

Responsibility is linked with 'empowerment', indicating a particular way in which the responsibility of family members (particularly parents) in performing their roles as familial caregivers is inflected: 'The primary responsibility for a family's welfare will always rest with parents' (SETF, 2008: 5). Families should be 'empowered to shape the package of support' (SETF, 2008: 12). Aiming High for Disabled Children: Better Support for Families (HM Treasury and DCFS, 2007: 15) explicitly defines empowerment in relation to 'rights and responsibilities for individuals'. The 'transformative' concept of 'personalisation' links empowerment with the exercise of choice over services and a concomitant expectation that individuals and those caring for them will exercise responsibilities to make informed choices (DoH, 2008).

Caring responsibilities are intrinsic to family life: 'the role of the individual is to recognise that caring for a family member, friend or partner is one of the responsibilities we all potentially face as part of family life' $(\mathrm{DoH}, 2008: 36)$. In support of this, carers have responsibilities to look after their own health, to be an effective care partner, and to maximise choices open to those they care for (Barnes, in press). Care within families is central to the creation of a 'fairer Britain' and support offered by Government to carers is offered in recognition of this. Similarly, responsibility is placed on the family as a discrete unit to improve outcomes for 'children whose life chances are seriously undermined by the chaotic and unstable families into which they are born' (Cabinet Office, 2009). Here families are constructed as both the source of, and response to the problem.

This discourse centres on existing normative constructions that place families in the buffer zone between the state and individuals. The family is the key unit of responsibility throughout government strategies relating to citizenship and care, and in particular to the protection of children (DCSF, 2009).

The resourceful family/the risk managing family

Strong, stable families are the bedrock of our society. Families give children the love and security they need to grow up and explore the world, and the moral guidance and aspiration to make the most of their talents and be good citizens. (DCSF, 2010: 3)

The dual notion of the family as resourceful and risk managing encompasses two separate but intertwined discourses. One constructs the family as highly resourceful and the other as the most appropriate risk-managing unit in relation to children. The family therefore becomes a place of security: 'joy, warmth and security of normal family life' (HM Government, 2003: 1); a 'source of strength and support' (SETF, 2007); a

\section{CAMBRIDGE JDURNALS}


provider of 'love, strength and support to get through hard times and overcome problems' (SETF, 2007) and 'the place for nurturing happy, capable and resilient children' (DCSF, 2007).

However, families are sometimes overburdened, particularly in relation to the costs of care: 'many families find it difficult to balance work with the care needs of friends and relatives without significantly impacting on their own standard of living, esteem and independence' (HM Treasury and DCSF, 2007). There is an assumption throughout policy documents that it is the 'good' unbroken family that is resourceful and is therefore ascribed the role of responsible carer and maintainer of pro social behaviour. But families can only be 'trusted' and regarded as experts if they accept responsibility to behave in ways consistent with official positions (SETF, 2007: 57). Thus to be 'expert care partners' carers must enable 'a family member the chance to experience maximum choice and control over their own life' (HM Government, 2007: 4). This is one example of the failure of much official discourse to engage adequately with the relational characteristics of family life.

\section{Family or families?}

The documents reviewed were drawn from different government departments, including those whose primary focus is the family (DCSF), and those that use family as a key social unit for determining specific policy action (e.g. DfT's social inclusion policy stream). Yet throughout, the term 'family' is used narrowly, primarily to denote the relationship between parents and their children.

In every document reviewed, the term 'family' is used in reference to children, including when the focus is on care for adults, e.g. caring for adults to enable them to care for children (HM Government, 2009). Children and parents are located in relation to each other and to the professionals they encounter, rather than wider caring relationships (cf. Williams, 2003). This is despite some calls for a wider definition of family. For example: 'Assumptions must not be made that everyone is heterosexual ... there should always be wider definitions of terms such as "family" and "carers"' (Quote from a consultee in Shaping the future of care, HM Government, 2009: 59). Families are also defined as discrete social units that are different from others: 'groups of people or families' (DfT, 2006: 16), families and the wider community (SEU, 2003: 59); 'citizens, families and communities' (HM Government, 2007: 3).

Every Child Matters (HM Government, 2003: 39) states that 'by bringing policy on parenting and family support into the Department for Education and Skills [now DCSF], alongside policy on children, the government has put it at the heart of children's services'. However, in spite of renaming the department to highlight the significance of family as an object of policy, and commissioning an evidence paper on this topic (Cabinet Office and DCSF, 2008: 110), little attention is given to the diversity of what family means in practice. Furthermore, the departmental separation of policy responsibility for children and families (DCSF) from that for 'adults' $(\mathrm{DoH})$ does not encourage a multi-generational conception of family.

There is an apparent acknowledgement of the dynamic and diverse nature of family life, but this wider construction of family is not consistently applied or reflected in the substance of policies. Some documents do refer to wider representations of the family, as extending beyond the parent-child relationship. For example, the Children's 
Plan (DCSF, 2007: 19) refers to 'lone parent families, step families and families where children are brought up by their grandparents'; the recently published Think Family Toolkit (DCFS, 2009: 2) refers to 'mothers, fathers, brothers, sisters, grandparents, step family and extended family members'; and Reaching Out: Think Family (SETF, 2007: 8) to 'increasing diversity in family composition and structures'. In addition, there is little acknowledgement of cultural differences between families. The example of a Sikh family in relation to intergenerational care in the DoH carers' strategy (2008: 24) is tokenistic and undeveloped.

The notion of family is constructed through interlocking and often competing discourses, based on normative assumptions that do not reflect families in practice. At one point, families are invoked as nurturers of future citizens, as enablers of citizenship and as essential to the achievement of social justice. At another, they are the source of social breakdown and creators of anti-social citizens/deniers of citizenship. Despite recognition of the need for gendered assumptions about caring responsibilities to be rejected (HM Treasury and DCSF, 2007; HM Government, 2009; DWP, 2009), these discourses are highly gendered and generational. The concept of family is locked into normative assumptions about the role of women within the nuclear family and the family is constructed in a particular stage of the lifecourse that is associated with childbearing and childcaring.

None of the documents discuss the role of older people in families beyond their role as child carers and receivers of care, despite the importance of intergenerational relationships in different contexts (Pain, 2006). Older people who care for children are given special status in families: 'family friendly must not mean welcoming and accessible only to mothers and fathers, but to other members of the family too, especially grandparents who provide care for grandchildren' (DWP, 2009). The Children's Plan (DCSF, 2007) recognises the role of grandparents in childcare and of families caring for older relatives and of young carers caring for family members.

Finally, whilst little explicit attention is given to the spatial dimension of family life (Duncan and Smith, 2002), a number of documents (HM Government, 2003; DfT, 2006; $\mathrm{DoH}, 2008$ ) connect ideas of family with that of 'home'. The family 'home' is constructed as a place of safety and security in relation to children in care, and:

The best environment for the person being supported is very often their normal social environment - home... the aim of the strategy in focusing on personalised services is to support people and their carers in their own homes and communities wherever possible. (DoH, 2008: 37).

As well as constructing a notion of the 'family home', DfT documents (2006, 2007) develop a notion of family based on family travel and the 'family car' and these are tied into spatial and social constructions of 'immediate family'. There is also some recognition in one DoH report of the geographical dispersion of families (DoH, 2008), but this is not developed elsewhere.

\section{Conclusion}

This discursive analysis of organisational constructions of family produces knowledge about dominant discourses that inform policy and usage. Such discourses are interpreted, 
re-interpreted and re-constructed at various levels of policy-making and practice by those who work with, support or seek to intervene in the lives of families. Those with access to privileged knowledge of family practices must negotiate a balance between institutional prescriptions of family and their lived experiences of what family means in practice. This is reflected in policy documentation, which attempts to assimilate the experiences of both practitioners and the families they have engaged with. For example, in Every Child Matters (HM Government, 2003) the only mention of 'extended family' can be found in one of the examples of good practice from Birmingham Local Education Authority. In order to develop our understanding of the way in which family policy may be impacting on family lives we need to explore how such discourses are embedded in practice, how practitioners determine 'what sort' of family they are encountering, how this affects the way in which they seek to work with/support families in difficulty, and how, in turn, such practice contributes to the different constructions of family.

\section{Note}

1 Department of Communities and Local Government: Sustainable Cities and the Ageing Society: The Role of Older People in an Urban Renaissance (DCLG, 2004); Intergenerational Relations and Practice in the Development of Sustainable Communities (Pain, 2006); Inspiring Communities Grant Programme (Communities and Local Government, 2009); Department for Children, Schools \& Families: Every Child Matters Green Paper (DCSF, 2003a); Every Child Matters: The Next Steps (DCSF, 2003b); Every Child Matters: Change for Children (DCSF, 2004); Children's Plan: Building Brighter Futures (DCSF, 2007); Aiming High for Disabled Children (AHDC): Better Support for Families (HM Treasury and DCSF, 2007); Families in Britain: An Evidence Paper (Cabinet Office and DCFS, 2008); New Opportunities: Fair Chances for the Future (joint White Paper Cabinet Office, DCSF, DoH, DCLG, Home Office, DWP and others, 2009); Think Family Toolkit (DCSF, 2009); Delivering on the Children's Plan: Safe from Bullying on Journeys (DCSF, 2009); Support for All: Families and Relationships Green Paper (DCSF, 2010); Department for Transport: Older People, Their Transport Needs and Requirements (DfT, 2001); Young People and Transport: Understanding Their Transport Needs and Requirements (DfT, 2006); Understanding the Travel Aspirations Needs and Behaviour of Young Adults (DfT, 2007); Resource Guide for Local Authorities: Transport Solutions for Older People (DfT, 2009); Department of Health: Putting People First (DoH, 2007); Carers at the Heart of 21st Century Families (DoH, 2008); Shaping the Future of Care Together (HM Government, 2009); Department for Work and Pensions: Building a Society for all Ages (DWP, 2009); Home Office: Respect Action Plan (Home Office, 2006); Social Exclusion Task Force: Making Connections: Final Report on Transport and Social Exclusion (SETF, 2003); Reaching out, Social Exclusion Action Plan (SETF, 2006); Reaching Out: Think Family (SETF, 2007); Think Family: Improving the Life Chances of Families at Risk (SETF, 2008); Families at Risk Literature Review (Morris et al., 2008).

\section{References}

Artaraz, K., Thurston, M. and Davies, S. (2007), 'Understanding family support provision within the context of prevention: a critical analysis of a local voluntary sector project', Child and Family Social Work, 12, 4, 306-15.

Barnes, M. (2006), Caring and Social Justice, Basingstoke: Palgrave.

Barnes, M. (in press), 'Caring Responsibilities: the making citizen carers?', in J.E. Newman and E. Tonkens (eds.), Active Citizenship in Europe, Amsterdam: University of Amsterdam Press.

Beck, U. and Beck-Gernsheim, E. (1995), The Normal Chaos of Love, Cambridge: Polity Press.

Cabinet Office (2008), "Ministers launch new "think family" approach to help vulnerable parents and children', Press release CAB/003/08, available at www.cabinetoffice.gov.uk/social_exclusion_ task_force/news/2008/080110_families.aspx. 
Cabinet Office (2009), New Opportunities: Fair Chances for the Future, White Paper, London: The Stationery Office.

Cabinet Office Strategy Unit and Department for Children, Schools and Families (2008), Families in Britain: An Evidence Paper, London: Cabinet Office.

Chase, S. E. and Rogers, M. F. (2001), Mothers and Children: Feminist Analyses and Personal Narratives, New Brunswick: Rutgers University Press.

Clark, L. (1996), 'Demographic change and the family situation of children', in J. Brannen and M. O'Brien (eds.), Children in Families, London: The Falmer Press.

Department for Children, Schools and Families (DCSF) (2003a), Every Child Matters Green Paper, London: DCSF.

Department for Children, Schools and Families (DCSF) (2003b), Every Child Matters: The Next Steps, London: DCSF.

Department for Children, Schools and Families (DCSF) (2004), Every Child Matters: Change for Children, London: DCSF.

Department for Children, Schools and Families (DCSF) (2007), The Children's Plan, London: DCSF.

Department for Children, Schools and Families (DCSF) (2008), The Children's Plan: One Year On, London: DCSF.

Department for Children, Schools and Families (DCSF) (2009), Think Family Toolkit, London: DCSF.

Department for Children, Schools and Families (DCSF) (2010), Support for All: The Families and Relationships Green Paper, London: The Stationery Office.

Department of Communities and Local Government (DCLG) (2004), Sustainable Cities and the Ageing Society: The Role of Older People in an Urban Renaissance, London: DCLG.

Department of Communities and Local Government (DCLG) (2009), Inspiring Communities Grant Programme, London: DCLG.

Department for Transport (DfT) (2006), Young People and Transport: Understanding Their Transport Needs and Requirements, London: DfT.

Department for Transport (DfT) (2007), Understanding the Travel Aspirations: Needs and Behaviour of Young Adults, London: DfT.

Department for Work and Pensions (DWP) (2009), Building a Society for all Ages, London: The Stationery Office.

Department of Health (DoH) (2008), Carers at the Heart of 21st Century Families and Communities: A Caring System on Your Side, a Life of Your Own, London: DoH.

Duncan, S. and Edwards, R. (1999), Lone Mothers, Paid Work and Gendered Moral Rationalities, Basingstoke: Macmillan Press.

Duncan, S. and Smith, D. (2002), 'Geographies of family formations: spatial differences and gender cultures in Britain', Transactions of the British Geographical Society, 27, 4, 471-93.

Finch, J. (1989), Family Obligations and Social Change, Cambridge: Polity Press.

Gubrium, J. F. and Holstein, J. A. (1990), What is Family, Mountain View, CA: Mayfield Publishing Company.

Hendrick, H. (2003), Child Welfare, Bristol: The Policy Press.

HM Government (2003), Every Child Matters Green Paper, London: The Stationery Office.

HM Government (2007), Putting People First, London: HM Government.

HM Government (2009), Shaping the Future of Care Together, London: The Stationery Office.

HM Treasury and Department for Children, Schools and Families (2007), Aiming High for Disabled Children: Better Support for Families, London: HM Treasury.

Home Office (2006), Respect Action Plan, London: Home Office.

James, A., Jenks, C. and Prout, A. (1998), Theorizing Childhood, Cambridge: Polity Press.

Morris, K., Hughes, N., Clarke, H., Tew, J., Mason, P., Galvani, S., Lewis, A., Loveless, L., Becker, S. and Burford, G. (2008), Think Family: A Literature Review of Whole Family Approaches, London: Cabinet Office. 
Newman, J. E. and Tonkens, E. (eds.) (in press), Active Citizenship in Europe, Amsterdam: University of Amsterdam Press.

Nixon, J. and Parr, S. (2008a), 'Family Intervention Projects - sites of resilience, resistance and domination', in M. Barnes and D. Prior (eds.), Subversive Citizens: Power, Agency and Resistance in Public Policy, Bristol: Policy Press.

Nixon, J. and Parr, S. (2008b), 'Family Intervention Projects and efficacy of parenting interventions', in M. Blyth and E. Solomon (eds.), Prevention and Youth Crime: Is Early Intervention Working? Bristol: The Policy Press.

Pain, R. (2006), Intergenerational Relations and Practice in the Development of Sustainable Communities, Background Paper for the Office of the Deputy Prime Minister, London: ODPM.

Parr, S. and Nixon, J. (2008), 'Rationalising Family Intervention Projects', in P. Squires (ed.), ASBO Nation: The Criminalisation of Nuisance, Bristol: The Policy Press.

Sevenhuijsen, S. (2003), 'Trace: a method for normative policy analysis from the ethic of care', Paper presented at the Seminar 'Care and Public Policy, Centre for Women and Research', University of Bergen.

Silva, E. B. and Smart, C. (eds.) (1999), The 'New' Practices and Politics of Family Life, London: Sage Publications.

Smart, C. and Neale, B. (1999), Family Fragments, Cambridge: Polity Press.

Social Exclusion Task Force (2003), Making Connections: Final Report on Transport and Social Exclusion, London: The Stationery Office.

Social Exclusion Task Force (2006), Reaching Out: An Action Plan on Social Exclusion, London: The Stationery Office.

Social Exclusion Task Force (2007), Reaching Out: Think family Analysis and Themes from the Families at Risk Review, London: Cabinet Office.

Social Exclusion Task Force (2008a), Think Family: Improving the Life Chances of Families at Risk, London: Cabinet Office.

Social Exclusion Unit (2003), Transport and Social Exclusion: Making the Connections, London: Cabinet Office.

Tronto, J. C. (1993), Moral Boundaries: A Political Argument for an Ethic of Care, New York: Routledge.

White, C., Warrener, M., Reeves, A. and La Valle, I. (2008), 'Family intervention projects: an evaluation of their design, set-up and early outcomes research report', DCSF-RW047, DCFS, London.

Williams, F. (2003), 'Response to the Government Green Paper Every Child Matters on behalf of ESRC Research Group on Care, Values and the Future of Welfare (CAVA)', DfES, November 2003.

Williams, F. (2004), Rethinking Families, London: Calouste Gulbenkian Foundation.

\section{CAMBRIDGE JDURNALS}

